\title{
Some Important Characteristics of Asset Bubbles and Financial Crises
}

\author{
Paul S. L. Yip \\ Economics Department, Nanyang Technological University, Singapore \\ Email: aslyip@ntu.edu.sg
}

How to cite this paper: Yip, P.S.L. (2018) Some Important Characteristics of Asset Bubbles and Financial Crises. Modern Economy, 9, 1137-1168. https://doi.org/10.4236/me.2018.97075

Received: March 17, 2018

Accepted: July 3, 2018

Published: July 6, 2018

Copyright $\odot 2018$ by author and Scientific Research Publishing Inc. This work is licensed under the Creative Commons Attribution International License (CC BY 4.0).

http://creativecommons.org/licenses/by/4.0/

\begin{abstract}
This paper first discusses the major characteristics of the seeding stage, the development stage and the final stage of an asset bubble. In particular, it emphasizes the role of expectation, some major changes in economic behaviors, financial leveraging, some important vicious cycles, upward spirals and herding behavior in the eventual development of an asset bubble. Thereafter, it discusses the policy implications of such an analysis. The second half of the paper extends the discussion to some important changes in economic behaviors, financial deleveraging, vicious cycles and downward spirals that would push an early-developed financial crisis into a full-blown economic crisis. Based on the characteristics and the experience of some major financial crises in the past few decades, the paper discusses policy measures that could be adopted during the crisis period and the post-crisis recession.
\end{abstract}

\section{Keywords}

Asset Bubble, Financial Crisis, Expectation of Asset Inflation, Changes in Economic Behaviors, Vicious Cycles, Financial Leveraging and Deleveraging, Herding Behavior, Quantitative Easing

\section{Introduction}

In this paper, the author will first discuss the major characteristics of the seeding stage, the development stage and the final stage of an asset bubble. ${ }^{1}$ In particular, he will highlight the role of expectation, some powerful changes in economic behaviors, financial leveraging, some important vicious cycles, upward spirals and herding behavior in the eventual development of an asset bubble. Under-

${ }^{1}$ Based on the definition from Financial Times Lexicon, the author defines an asset bubble as a stage in which the price of an asset exceed valuation justified by fundamentals, making an eventual collapse likely. 
standing these characteristics will provide us important insight on how policy makers could pre-empt the development of an asset bubble, and hence avoid a bursting of bubble and then a financial crisis in the subsequent future. Thereafter, the author will extend the discussion to some important behavioral changes, financial deleveraging, vicious cycles and downward spirals that would push an early-developed financial crisis into a full-blown economic crisis. Again, the discussion of these characteristics will provide useful insight on how to mitigate a financial crisis, which would also substantially reduce the economic pains during the crisis period and the post-crisis recession.

The arrangement of the paper is as follows. Section 2 is a brief review on the literature that is most related to this paper. In Section 3, the author will provide a detailed discussion of the major characteristics of an asset bubble and the policy implications of such an analysis. In Section 4, he will provide similar discussion on the major characteristics of a financial crisis and potential policy measures that could mitigate the economic pains caused by the crisis. Section 5 is the conclusion.

\section{Literature Review}

This paper is related to the literature on the US dollar bubble in 1980-84, the bursting of the Japanese property and stock market bubbles in the late 1980s, the Asian financial crisis in 1997-98, the China stock market bubble in 2006-07, the Global Financial Tsunami in 2008-09, the European Debt Crisis in 2010-12, China's mini exchange rate crisis and another bursting of stock market bubble between August 2015 and early 2016, and the formation of property bubbles in Hong Kong and some other Asian economies in 2009-18. Within the vast literature on these asset bubbles and economic crises, there are some important articles that are highly related to this paper. In their discussion on the US dollar bubble in 1980-84, Frankel and Froot [1] [2] argued that more and more exchange rate market participants shifting from the "fundamentalist" approach to the "chartist" approach had provided the necessary fuel for the growth of the US dollar bubble at that time. In Section 3, the author will modify and extend their arguments to explain the growth of an asset bubble in the final stage and the high likelihood of an eventual bursting of the bubble.

On the Asian financial crisis in 1997-98, Radelet and Sachs [3], Furman and Stiglitz [4], Hutson and Kearny [5] and Goldstein [6] provided detailed discussion on the underlying and triggering causes of the crisis. In particular, they highlighted the role of sudden reversal of capital flows, self-fulfilling expectation, contagion effect and slowdown of export growth amid the internal weakness built up in the affected economies before the crisis. Examples of these internal weakness include the sharp rise in the current account deficit to GDP ratio to unstainable level, the sharp rise in unhedged short-term debt, the credit boom, financial institutions' substantial exposure to the asset market and misalignment of exchange rates. Yip [7] supplemented the discussion by highlighting the role 
of speculative attack by hedge funds as the triggering cause and the role of asset bubbles as another important underlying cause of the crisis. In particular, the book provided a detailed discussion of the currency attacks in most of the crisis-hit economies and the more sophisticated speculative attack in Hong Kong [7], the formation of property bubbles and stock market bubbles in 1990-97 in these economies due to the substantial capital inflows after the unchecked capital account liberalization in these economies in the 1980s (Chapter 1), the exchange rate crisis in 1997-98 as well as the policy measures and adjustment mechanism during the post-crisis recession (Chapter 4). Part of the discussion, especially on the move from an exchange rate crisis to a full-blown economic crisis, will be incorporated in this paper with further refinements.

For the case of stock market bubbles in China, Yao and Lu [8] and Yip [9] provided a detailed discussion on the formation and then the bursting of the mother shares bubble in 2006-08, Xiong and $\mathrm{Yu}$ [10] and Powers and Xiao [11] discussed the warrant bubble during the same period, while Liu, Gu and Lung [12] discussed the stock market bubble in 2014-15. Yip [13] [14] also discussed China's mini exchange rate crisis, substantial capital flight, drastic decline in foreign reserves and bursting of stock market bubble between August 2015 and mid 2016. The related analyses will be incorporated in this paper's discussion of the major characteristics of an asset bubble and financial crises.

In the early literature on the Global Financial Tsunami, Cecchetti [15] provided a detailed discussion of the early stage of the crisis and the policy responses of the Federal Reserve in the early stage. Mayer, Pence and Sherlund [16] discussed the attributes of the subprime mortgages and near-prime Alt-A mortgages as well as the rise of mortgage default between mid-2005 and mid-2007. Coval, Jurek and Stafford [17] explained how securitization and structured finance activities, such as the creation of collateralized debt obligation (CDO) and $\mathrm{CDO}^{2}$ through pooling and trenching, repackaged many kind of risky assets to vast quantities of misleading triple-A-rated securities. The huge accumulated amount of these structured finance products is believed to be one of the major causes for the deepening of the subprime crisis into a full-blown financial tsunami in the US. In the second batch of literature, Shleifer and Vishny [18] discussed the role of asset "fire sales" in depleting the balance sheets of financial institutions and aggravating the fragility of the US financial system during the financial tsunami. Mishkin [19] first reported how the crisis deteriorated from the first phase of a subprime mortgage crisis to the second phase of a full-blown global financial crisis. It then discussed the US policy responses to the second phase of the financial crisis. In particular, it discussed:

1) the conventional monetary policies (e.g., reduction of the federal fund rate towards zero) in the early stage, and the unconventional monetary policies (e.g., Quantitative Easing) in the later stage;

2) the bank stress test organized by the US Treasury; and

3) bailout of some banks and financial institutions with the TARP (Troubled 
Asset Relief Program) fund, and highlighted that these measures had helped to prevent a far deeper recession and even possibly a depression. Yip [9] also explained that the Quantitative Easings in the US helped the global economy to avoid a great depression similar to that in the 1930s. It then highlighted that the Quantitative Easings in the US could seed the possibility of asset bubbles in Asia and then a bursting of these asset bubbles at the later phase of the global economic recovery. Some of the discussion on the move from an early crisis to a full-blown economic crisis and the important policy measures adopted at that time will be incorporated in this paper with a new theoretical framework and a deeper analysis on the potential application of the policy measures to mitigate the damages of financial crises in the future.

There is also a vast literature on the causes and the deepening process of the European Debt Crisis as well as the policy measures adopted. In particular, Shambaugh [20] highlighted that there were in fact three interlocking crises (i.e., the banking crisis, the sovereign debt crisis and the growth/macroeconomic crisis) that together caused the depressed outcomes. For example, the problems of weak banks and high sovereign debt were mutually reinforcing, and both deepened the recession that in turn exacerbated the baking crisis and the sovereign debt crisis. Thus, policy measures failed to take into account the interdependent nature of the problems would likely to be incomplete or even counterproductive. It then discussed the important policy measures adopted at that time and proposed some interesting and useful policy measures. Lane [21] echoed Shambaugh's three interlocking crises discussion but renamed the growth crisis as macroeconomic imbalance. Lothian [22] then discussed the role of the chronic government overspending and hence the resultant high debt/GDP ratio in Greece and Portugal, the role of the formation and then the bursting of housing bubbles in Spain and Ireland, as well as the pre-crisis credit boom, current account deficit and financial imbalance in these economies as the underlying causes of the crisis. The above papers also provided interesting discussion on the deepening process of the crisis, while Panico and Purificato [23] provided a detailed chronology of the major events and policy measures implemented during the crisis. Meanwhile, Peersman [24] and Gambacorta et al. [25] showed that the European Central Bank (ECB) unconventional monetary policies increased output and inflation. Szczerbwicz [26] found that the most spectacular ECB unconventional monetary polices, namely the Outright Monetary Transactions (OMTs), the 3-year Long Term Refinancing Operations (3-yr LTROs), the long-term sovereign bond purchases (Securities Markets Program, SMP), and the covered bond purchases (CBPP1 and 2) were effective in reducing the high borrowing costs for the banks and the crisis-hit governments. Some of the interesting analyses will be integrated into this paper's discussion on the characteristics of financial crises and post-crisis recessions.

Finally, Yip [27] [28] noted that the 2008-09 financial crisis in the US had 
contributed to two major aftershock crises, one in Europe and another in East Asia. That is, when Greece, Portugal, Ireland, Spain and Italy raised their fiscal expenditure to stimulate demand during the 2008-09 global financial tsunami, the policy also substantially increased the high debt/GDP ratio in these economies, which had in turn triggered the outbreak of the European Debt Crisis in 2010. On the other hand, while the global Quantitative Easings helped avoid the 2008-09 global financial tsunami from triggering a Great Depression similar to that in the 1930s, the measure also substantially increased the liquidity and sparked off the formation of property bubbles in many East Asian economies. After a detailed analysis of the property bubble and curbing measures in Hong Kong, Yip [27] highlighted the high likelihood of an eventual bursting of the gigantic property bubble in Hong Kong, which could in turn trigger another Asian Financial Crisis through the contagion effect. After extending the analysis to the property markets in other East Asian economies, Yip [28] concluded that another Asian financial crisis would be a question of time instead of whether-or-not. Again, the related analysis will be integrated in Sections 3 and 4.

\section{Some Important Characteristics of Asset Bubbles}

\subsection{The Three Stages of an Asset Bubble}

Based on the characteristics of previous asset bubbles, the author has in his previous publication partitioned an asset bubble period into the following three stages: the seeding stage, the development stage and the final stage. Down below, the author will elaborate how the identification of the characteristics in each of the three stages will provide a better understanding of the formation of an asset bubble. Thereafter, he will discuss the policy implications of such an analysis.

\subsubsection{The Seeding Stage}

According to the discussion, the seeding stage usually occurs when the asset price has a chance to exhibit a sustained rebound (or rise) from a trough for a few months or quarters. ${ }^{2}$ For example, as shown in Figure 1, the Chinese stock market was able to gain an upward inertia after a few months of sustained recovery (or rise) from its trough in mid-2005.

Similarly, as shown in Figure 2, the property price index in Hong Kong was able to gain an upward inertia after a few months of sustained rise or recovery from early 2009. The sustained rise in the asset price in the first few months or quarters would then create an expectation of further rise in the asset price (i.e., expectation of asset inflation). This change in expectation will in turn trigger some major changes in economic behaviors, which would then fuel further rises in the asset price.

${ }^{2}$ Note that not all rebounds from the trough would eventually lead to an asset bubble. However, as will be explained in Section 3.1.3, if the asset price has the chance to exhibit a sustained recovery (or rise) from the trough for a few months or quarters so that it can trigger an expectation of further rise in the asset price, then the chance of an eventual bubble will be much higher (see Section 3.3 for the more detailed discussion and the related policy implications). 


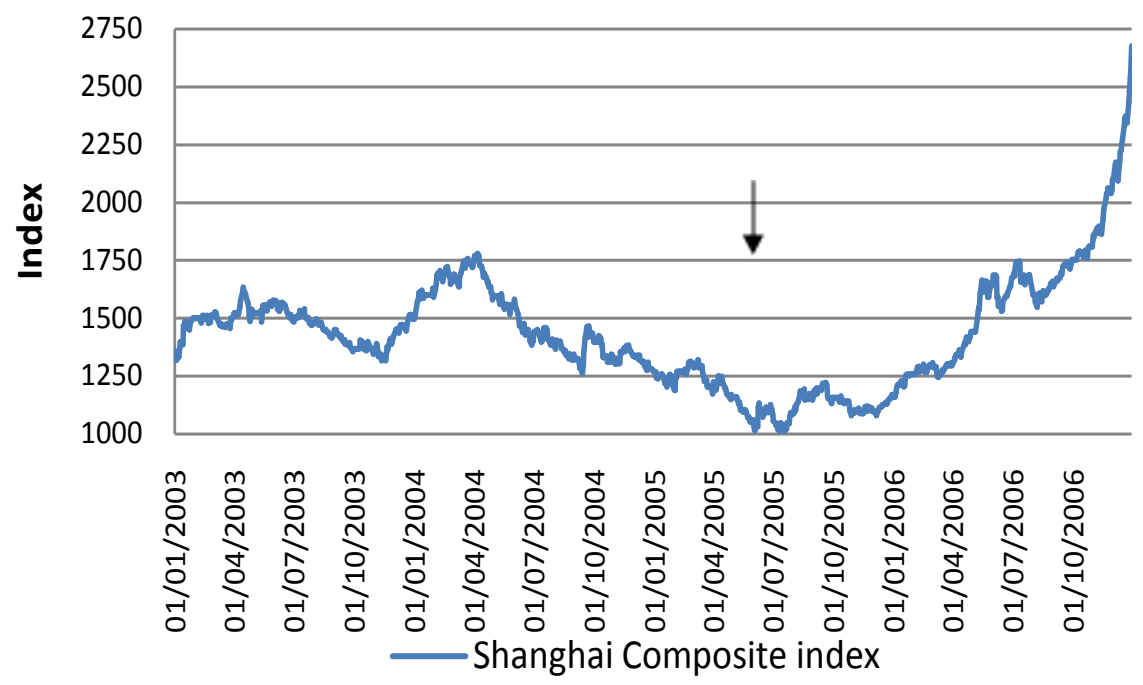

Figure 1. The seeding stage of the bubble.

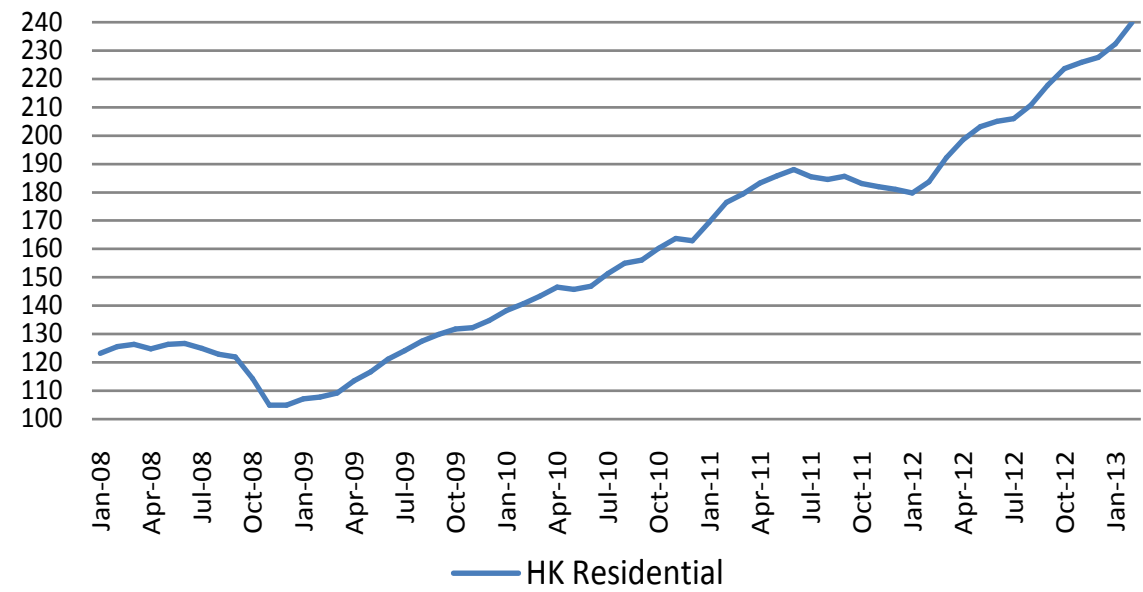

Figure 2. HK property price index (residential).

\section{1) Direct increase in asset demand}

For example, the expectation of further rise in the asset price could substantially augment individuals' and firms' demand for the asset. Throughout the seeding stage, the development stage and the final stage, individuals and firms will invest more and more funds into that asset. Some will even increase their investment in that asset with funds originally meant for other purposes (e.g., retirement money or life-time savings for individuals; and working capital, investment funds or other company money for firms). Many of the market participants will also increase their investment in the asset through higher leverage and borrowing. In fact, during China's stock market bubble in 2006-07, many of the market participants had invested their lifetime savings in shares while many others had substantially increased their borrowing for shares investment. Managers or owners of firms had also used company money and borrowed money for shares investment. Similarly, during the first year of the rebound (or rise) of 
Hong Kong and Singapore property prices from their troughs in 2009, the upward inertia of property prices and hence the expectation of further rise in property prices also triggered a substantial increase in speculative demand and investment demand, which in turn pushed the two property markets into the development stage of a property bubble. The sustained rise in property prices in the development stage and the final stage had also triggered substantial panic demand as well as further increase in speculative demand and investment demand for properties.

\section{2) Monetary support for the increase in asset demand}

In addition to the above direct increase in the demand for the asset, there will also be behavioral changes on the monetary side that will provide the necessary fuel for further rises in the asset price. To understand this, first consider the following simple model:

$$
\begin{gathered}
M=C+D \\
M B=C+R R+E R \\
\text { and } M \equiv m \times M B
\end{gathered}
$$

where the money supply $(M)$ is the sum of cash $(C)$ and bank deposit $(D)$ held by the general public; the monetary base $(M B)$ is the sum of cash held by the general public and the required reserve $(R R)$ plus the excess reserve $(E R)$ held by the banks; and the money multiplier $(m)$ is defined as the amount of money supply $(M)$ created by the monetary base or high power money $(M B)$.

Defining $k$ as the general public's desired cash-to-deposit ratio, $r$ as the banks' required-reserve-to-deposit ratio, and $e$ as the banks' desired excess-reserve-todeposit ratio, one can get Equation (4) after substituting Equations (1) and (2) into identity (3):

$$
\begin{gathered}
m=\frac{M}{M B}=\frac{C+D}{C+R R+E R}=\frac{\frac{C}{D}+1}{\frac{C}{D}+\frac{R R}{D}+\frac{E R}{D}} \\
m=\frac{k+1}{k+r+e}
\end{gathered}
$$

which states that a fall (rise) in banks' desired excess-reserve-to-deposit ratio (e) will cause a rise (fall) in the money multiplier $(m)$. By appropriate re-arrangement, Equation (4) can also be rewritten as Equation (4'):

$$
\begin{gathered}
m=\frac{k+r+e+1-(r+e)}{k+r+e} \\
\Rightarrow m=1+\frac{1-(r+e)}{k+r+e}
\end{gathered}
$$

As the sum of the banks' required reserve and excess reserve has to be less than the total deposit (i.e., $R R+E R<D)$, the $(r+e)$ in Equation (4') has to be less than 1 . Therefore, according to Equation (4'), a fall (rise) in the general public's desired cash-to-deposit ratio $(k)$ will cause a rise (fall) in the money multiplier 
$(m)$.

Unlike standard textbooks which assume the parameters $k$ and $e$ in Equation (4) or (4') are fixed and the monetary base $M B$ is exogenously determined by the central bank, the author would like to highlight that the following changes in economic behaviors during a property or stock market boom will cause a substantial reduction in $k, e$ and a substantial increase in $M B$ : With the expected rise in asset price, some investors will try to increase their asset investment by economizing their cash holding, thus causing a reduction in their desired cash-todeposit ratio $(k)$. According to Equation ( $\left.4^{\prime}\right)$, this will cause an increase in the money multiplier $(m)$. Meanwhile, in view of the higher demand for loans during the asset boom, banks would like to make more loans (probably with higher interest rate) by reducing their desired excess-reserve-to-deposit ratio (e). According to Equation (4), this will also cause a rise in the money multiplier $(m)$. Furthermore, during the asset boom, banks will soon find that just running down their desired excess-reserve-to-deposit ratio will not be enough to satisfy the increase in demand for loans. As such, they will soon attempt to borrow overseas, and then convert the foreign currency loans into domestic currency to satisfy the higher domestic loans. This would cause a substantial increase in monetary base $(M B)$, which will in turn cause a multiple creation of deposit $(D)$ and money supply $(M)$. On top of the banks' overseas borrowing, the asset boom could also induce substantial short-term capital inflows or hot money into the domestic asset market. These inflows will also substantially increase the monetary base.

Thus, the expectation of further rise in the asset price will induce changes in economic behaviors such as a fall in both the general public's desired cash-to-deposit-ratio $(k)$ and the banks' desired excess-reserve-to-deposit-ratio $(e)$, which will in turn cause a rise in the money multiplier $(m)$. In addition, there will also be a significant increase in banks' overseas borrowing and short-term capital inflows. These changes in economic behaviors will cause a substantial increase in the monetary base $M B$. As a result, there will be both an increase in $m$ and $M B$. According to Equation (3), i.e., $M=m \times M B$, these will cause an enormous increase in money supply $(M)$, which will in turn fuel and support further rises in asset price in all the three stages of the asset bubble. ${ }^{3}$

3) Past example of a substantial increase in money supply during an asset bubble

In fact, as documented in the literature on the 1997 Asian financial crisis, banks in Thailand and many ASEAN economies had borrowed substantial short-term US dollar loans (i.e., less than 1 year) to finance the increase in domestic loans during the asset bubble in 1990-97. On top of that, the rampant rises in domestic shares prices and property prices at that time had induced enormous short-term capital inflows or hot money into these economies. Because of the rise in the money multiplier and the monetary base, the loan growth

${ }^{3}$ Note that without an increase in the money supply due to the behavioral changes on the monetary side, there will be a limit in the increase in asset demand and hence the size of the asset bubble. 
in these economies were well above the real GDP growth during the bubble period. For example, as reported in Yip [7], the average domestic credit growth in Thailand, Malaysia and Indonesia were in the range of $20 \%-25 \%$ per annum between 1992 and 1996, while the average real GDP growth were only 7\% - 10\% per annum during the same period. With the sharp increase in money supply and credit, the domestic debt to GDP ratio in these economies surged by $26 \%$ 78\% between 1992 and 1997, thus fueling the asset bubbles in these economies and making them vulnerable to a financial crisis in the subsequent future.

\subsubsection{The Development Stage}

Once the expectation of further rise in asset price causes the above changes in economic behaviors, the asset market has entered the development stage. At this stage, the changes in economic behaviors and the sustained rise in asset price would trigger a large number of powerful vicious cycles, upward spirals and increase usage of built-in leverages (see the details in the subsequent section). It should be highlighted that the upward force due to these changes in economic behaviors would be enormous. For example, as noted in Yip [9], during all the three stages of China's stock market bubble in 2006-07, tens of million people (including businessmen, employees, housewives, retirees and students) had changed from non-investors to investors of shares. Firms also used huge amount of company money and/or borrowed huge amount of money for shares investment. Similarly, according to Yip [27] [28], during all the three stages of Hong Kong's property bubble between early 2009 and 2018, the increase in the speculative demand, investment demand and then panic demand was so enormous that the property price index has more than tripled during that period.

1) Large number of powerful vicious cycles

On top of the above ongoing changes in economic behaviors, there will also be the emergence of a few important vicious cycles that would further fuel the rise in the asset price. For example, there will be a vicious cycle between the rise of property prices and the rise of shares prices. That is, a rise in property prices will raise the profits and hence the prices of property shares, which will in turn raise the shares prices of other sectors through an indicator effect, a portfolio adjustment effect and other spillover effects. The rise in share prices will in turn induce some share investors to invest in more properties and hence support further rise in property prices. Furthermore, there will be a series of vicious cycles among the rises of asset prices, consumption, investment and output. That is, a rise in property prices and share prices will increase consumption through the wealth effect, while a rise in property prices will increases the developers' investment in real estate development and a rise in shares prices will increase firms' investment through the Tobin's q effect. These rises in consumption and investment will increase output through the standard multiplier effect. The rise in output will increase investment through the accelerator effect which will in turn cause more rounds of rise in output and consumption through the standard multiplier effect. The increase in aggregate demand and output will increase 
firms' profits and shares prices, and the rise in output and wealth will increase property prices and shares prices through higher demand for assets. There will also be a vicious cycle between the rise in asset prices, capital inflows and the rise in money supply. As noted in part B of Section 3.1.1, a rise in asset price will attract investments by foreign investors (i.e., capital inflows). Under a fixed exchange rate system or a managed floating, the capital inflows will cause a substantial rise in monetary base and hence multiple creation of money supply, which will in turn fuel another round of powerful rise in asset prices and capital inflows.

\section{2) Upward spiral}

Meanwhile, there will be an upward spiral among property prices, rentals, general prices and wages, which would again fuel or support the rise in property prices. For example, higher property prices will cause higher rentals. The higher rentals will induce workers to ask for higher wages, which will in turn induce suppliers to increase their prices. The higher rentals, wages and general price level will support further rises in property prices, thus resulting in an upward spiral among these nominal variables. As explained, changes in economic behaviors on the monetary side would cause an increase in money supply to support the upward spiral.

\section{3) Built-in leverages}

On top of the above vicious cycles and upward spirals, the increased usage of the built-in leverages in the financial system would also fuel the rise in the asset price. For example, during the a stock market boom, more stock investors would use more shares financing facilities through margin trading or more stock derivatives such as stock futures, warrants, call options and callable bull contracts. As the margin trading involve a borrowing from the brokerage houses or banks, the increase in the leverage would mean more money invested in the shares. Meanwhile, as financial institutions that issued the warrants, call options and callable contracts would hedge or at least partially hedge against the implied risk by buying the mother shares, the increase in demand for these derivatives would cause an increase in the demand for the mother shares. Thus, both the margin trading and the stock derivatives would provide the necessary leverages and funding facilities to support the increase in the demand for shares, which will in turn fuel the stock market boom. Along with the increase in leverages by individual investors, increase in leverages by financial institutions will be even more striking. For example, from news reports on the failure of the Lehman Brothers and the sale of Merrill Lynch to the Bank of America in 2008-09, these investment banks were betting heavily in the financial market with high leverages (e.g., more than 30 times for Lehman Brothers). Similarly, during the property boom, the rise in property prices and hence the rise in the banks' valuation (and the collateral values) of the properties would enable property owners to increase their existing mortgage loans with banks through a refinancing (or "cash out") arrangement, and then use the new borrowing as a down-payment for a new 
property investment. Worse still, some property investors will even borrow money for the down-payment by using overdraft facilities, renovation loans or other loan facilities offered by the banks, or second mortgage loans facilities offered by finance companies or developers. These abuses of loopholes would increase the leverages beyond the safety limit implied by the down-payment ratio. For example, if a property investor is able to borrow more money through the above loopholes so that he/she only needs to arrange cash equivalent to $5 \%$ $10 \%$ instead of $20 \%$ of the property price as a down-payment. His/her gearing in the property investment will be 10 - 20 times instead of 5 times. The much higher gearing will mean the same amount of investors' funds could support a much bigger property bubble, which will in turn imply greater likelihood of an eventual bursting. Worse still, it will increase the potential damages of the eventual bursting by making the property investors and the banks more vulnerable to a collapse in property prices.

4) Risk from unchecked financial innovations

On top of the built-in leverages, there could also be financial innovations that would fuel the asset bubbles. For example, during the asset bubble period before the 2008-09 financial tsunami in the US, there were emergence and then substantial increase of new financial products such as the mortgage backed securities (MBS), the collateralized debt obligations (CDOs) and even the CDOs ${ }^{2}$. As documented in literature on the Global Financial Tsunami in 2008-09, exponential growth of these new financial products had channeled enormous amount of funds for mortgage brokers to provide huge amount of mortgage loans to borrowers without appropriate screening. This had in turn contributed to the rampant rise of property prices in the US before the 2008-09 financial tsunami. Similarly, during China's stock market bubble between early 2014 and August 2015, the quick (and not properly checked) development of China's shadow banking had resulted in the rapid growth of some new financial products, such as the "wealth management products" and some new insurance products. These new financial products in turn channeled a substantial amount of funds for high leverage shares investment and hence fueled the growth of the stock market bubble at that time.

\subsubsection{The Final Stage}

In the final stage, the sustained and powerful rise in asset price in the previous stage will cause herding behavior. Unlike the changes in economic behaviors discussed in Section 3.1.1, the herding behavior will attract or force more participants to join the herd even if some of them believe that the asset price is highly overvalued. For example, during a stock market bubble, commodity bubble or exchange rate bubble, fund managers who tend to extrapolate the trend (i.e., behaving as the chartist highlighted by Frankel and Froot [1]) will voluntarily increase their investment in the asset). Even for those fund managers who believe the asset price is substantially overvalued, they will still be forced by performance pressure to increase their investment in the asset. Otherwise, the 
funds' performance will be worse than other funds before the bubble burst, and the poorer performance before the bursting will trigger redeeming pressure or outflows from the funds to other funds so that the fund manager might lose his/her job well before the end result prove that he/she is right. Thus, a rational fund manager still has to increase his/her investment in the overvalued asset, and hope that he/she could run away at the beginning of the bursting.

Similarly, during a property bubble, banks' chief executives and loan officers who tend to extrapolate the trend will voluntarily increase their loans. Even for those chief executives or loan officers who believe the property prices are substantially overvalued and an eventual bursting of the bubble with enormous damages is unavoidable, they are still under performance pressure to increase their loans to the property market. Otherwise, the banks' loan growth and profit growth would be worse than the other banks well before the bursting of the property bubble, which will cost them heavily in terms of job security and performance bonus. Thus, once the herding behavior is established, more and more fund managers will be attracted or forced by performance pressure to join the herd by speculating further rises in the asset price, even if some of them are aware of the risk of an eventual bursting. Similarly, banks' chief executives and loans officers will be attracted or forced by performance pressure to increase their loans through various methods (such as a substantial increase in overseas borrowing), even if some of them are aware that some of the loans might not be that safe and the credit boom might not be sustainable.

With more and more participants using more funds to join the herd, the herd will gain momentum. This will fuel the rise in the asset price, which will in turn attract or force more and more participants investing more funds in the asset. As a result, the growing momentum of the herd will keep pushing the asset price towards a gigantic bubble. At this stage, standard curbing measures will not be able to stop the asset price from rising. However, when close to $100 \%$ of the potential investors and funds have already gone into the asset market, the rise in asset price has to slow down and then stop. At this time, even a very mild negative shock can cause a fall in the asset price, which will in turn trigger herding behavior in the downward direction and causing a reversal of the above vicious cycles, spirals, financial leveraging, and changes in economic behaviors and expectation until the asset price plunges to a level well below the normal equilibrium level. In Section 3.2, the author will partition the potential bursting of bubble into two types according to their impacts on the economic, social and political stability on the economy.

\subsection{Two Types of Bursting}

Thus, once the bubble reaches the final stage, a bursting of bubble will be just a matter of time instead of whether-or-not. Here, there could be two types of bursting, and the eventual outcome will depend on whether there is a large enough negative shock to trigger a bursting of the bubble at the early part of the 
final stage. In the lucky case that there is a large enough negative shock at the early part of the final stage (i.e., before the bubble become too large), the bursting would only cause an economic crisis and severe recession, but not yet political and social instability. In the unlucky case that there is no large enough negative shock at the early part of the final stage, the bubble would have the chance to grow to an extremely big one. By then, even the government will be "kidnapped" by the gigantic bubble. That is, if it starts to curb the asset market, the curbing itself would be enough to trigger the bursting and the government will be blamed for such an action. Thus, a politically better choice for the government is to avoid touching the bubble. However, as explained in Section 3.1.3, when close to $100 \%$ of the potential investors have already invested close to $100 \%$ of their funds in the asset market, even a very mild negative shock is sufficient to trigger a bursting. By then, the crisis and recession could be so severe that there could be political and social instability (e.g., the ruling party would lose the election, and strong political leaders would lose people's respect and hence the moral authority for ruling).

One example of the second type of bubble bursting is the Asian financial crisis in 1997-98, after which most of the political leaders of the related countries had lost their power, and most of the central bank governors had lost their job. For example, the Prime Minster of Thailand and the President of South Korea had lost their elections after the crisis. Even for Mr. Suharto, the former Indonesia President once believed to be a strong man who would never lose his power, was forced to step down during the crisis. In addition, central bank governors in Thailand, Indonesia and other crisis-hit economies had also lost their jobs, with some being jailed or wanted because of inappropriate actions during the crisis.

In September 2007, the author was able to use the above examples to convince the Chinese leaders to curb the stock market bubble before it was too late. ${ }^{4}$ Fortunately, as China had not yet set up the stock futures market and the margin trading facility at that time, the damage of the bursting were further contained so that the bursting was reasonably localized (i.e., without substantial spillover effects to the other sectors) and the subsequent recession was relatively moderate.

\subsection{Policy Implications}

Understanding the above characteristics of the seeding stage, the development stage and the final stage of asset bubbles are important. For example, in those Asian economies with rampant asset inflation between early-1990 and mid-1997, the related central banks were aware of the risk of an asset bubble and its eventual bursting. As such, they did implement quite some curbing measures on their property markets. Nevertheless, every time they introduced a curbing measure, there was at most a knee-jerk in the property price index for just a few months.

${ }^{4}$ The proposal was submitted to the Chinese leaders as an internal report through the Xinhua News Agency. It was also published in the Hong Kong Economic Journal, a major financial newspaper in Hong Kong. 
Thereafter, the property price index would make another surge to a new high. Frustrated by the ineffective outcomes, many of these central bankers came out with the misleading conclusion that curbing measures would not have any effect on the property market.

Nevertheless, if these central bankers were equipped with the theoretical framework discussed in Section 3.1, they should know that that once an expectation of further rise in asset prices was formed, there would be powerful changes in economic behaviors, emergence of powerful vicious cycles, formation of upward spirals, increase in financial leverages and development of herding behavior. These would imply enormous upward force that would be far much greater than the relatively mild downward force created by the curbing measures.

As such, it was not right for these Asian central bankers to conclude that the curbing measures would not have any effect on the asset market. Instead, it was just these Asian central bankers' failure to recognize that during an asset boom, there would be enormous upward driving forces that would easily outdo the effect of the curbing measures. Thus, the author would like to point out the following three policy implications from the discussion of the characteristics of the three stages of an asset bubble:

1) As the forces behind the rise in the asset price in the development stage and the final stage are extremely powerful, it is always the best to use curbing measures to pre-empt any potential rampant asset inflation or asset bubble at the seeding stage (i.e., before the formation of an expectation of further rise in the asset price);

2) If an expectation of further rise in the asset price has been formed, the expectation will trigger significant changes in economic behaviors, upward vicious cycles, upward spirals, financial leveraging and upward herding behavior. If left unattended, the asset market will be pushed onto an automatic path towards a gigantic bubble; and

3) Once the asset market is in the development stage, the implied upward pressure will be far much greater than the cooling effect of standard curbing measures. By then, much greater curbing measures are needed before the asset inflation could be properly controlled. Otherwise, a gigantic asset bubble and then an eventual bursting will be unavoidable in the future.

\subsubsection{Two Contrasting Examples on the Application of the Above Policy Insights}

With the above conclusions and lessons drawn from previous asset bubbles, the author was able to warn from August $2009^{5}$ that the rebound of property prices in Hong Kong and Singapore at that time could eventually end up as a property bubble, and the related government should pre-empt the bubble formation by im-

${ }^{5}$ In August 2009, the Singapore government was inviting proposals on the long-term development of the Singapore economy. Instead of writing a proposal on the long-term development, the author took the opportunity to write a 4-page proposal warning the risk of a property bubble if the sustained rebound of Singapore's property prices at that time was left unattended. The proposal was well received by the related ministers at that time. 
plementing curbing measures at the seeding stage (i.e., in $2009 \mathrm{H} 2$ or $2010 \mathrm{H} 1)^{6}{ }^{6}$ Unfortunately, because of different reasons, both Hong Kong and Singapore missed the best time of pre-empting the property bubbles at the seeding stage. ${ }^{7}$

As a result, the sustained recovery or rise of property prices in these two economies between mid-2009 and mid-2010 had triggered an expectation of further rise in property prices and the subsequent changes in economic behaviors. These had in turn pushed the two property markets into the development stage with further changes in economic behaviors, emergence of powerful vicious cycles, development of upward spirals and increase in financial leverages. Fortunately, after the author's visit in 2012, the Monetary Authority of Singapore (MAS) was convinced that the property market in Singapore was already in the development stage so that very severe curbing measures were necessary to bring its property market out from the automatic path towards a huge bubble. Besides, Singapore's economic and monetary officials were well-trained and capable enough to design rather innovative severe curbing measures in its fifth, seventh and eight rounds of curbing. Despite the hard effort, its fifth and seventh rounds of curbing measures were only able to slow down the rise in the property price index. Fortunately, the very strong curbing measures in the eighth round managed to cause a soft correction of the property price index by about one percent per quarter between 2013Q4 and 2016Q4, thus resulting in a soft squeezing of the moderate property bubble to a much smaller and safer bubble.

Nevertheless, despite the author's two visits to the Hong Kong Monetary Authority (HKMA) and numerous of warning articles in the press at that time, the monetary officials in Hong Kong were not well-trained enough to be fully aware of the disastrous consequences if they were not determined enough to act. Furthermore, the monetary officials were not well trained and capable enough to design effective and severe enough curbing measures. Instead, they only copied Singapore's fifth and seventh rounds of curbing measures, which again could only help to slow down the rise in Hong Kong's property price index at that ${ }^{6}$ Since August 2009, the author had kept on providing such warnings in the form of policy proposals to the related ministers in Singapore, seminars in the Monetary Authority of Singapore (MAS) and the Hong Kong Monetary Authority (HKMA), letter to the of Chief Executive of Hong Kong, policy articles in the newspapers and interviews with the TV channels.

${ }^{7}$ With the same theoretical framework, the author was also able to warn from 2006Q2 that the sustained rebound of China's shares prices from the trough at that time could eventually end up as a stock market bubble. Unfortunately, the Chinese government at that time did not have the knowledge to appreciate the importance of the lessons that the author had drawn from previous asset bubbles. In particular, it did not have sufficient confidence or conviction on (and hence fail to act in response to) the author's warning that 1) once there is an expectation of further rise in the asset price, the chance of a bubble formation will be much higher than that under normal circumstances; and 2) it will be least costly to pre-empt the potential bubble at the seeding stage. Fortunately, with an internal reported in September 2007 through the Xinhua News Agency (also published in a major newspaper in Hong Kong), the author managed to convince the Chinese leaders to curb the stock market bubble. Nevertheless, a curbing at such a late stage did involve a relatively heavy, albeit not too disastrous, economic cost (see Chapter 8 of [9] for more details).

${ }^{8}$ Because of the law on privacy protection, banks and government departments in Hong Kong were not allowed to collect and disclose information on the total amount of loans owed by the mortgage loan applicant. As such, Hong Kong could not directly copy the TDSR (Total Debt Service Ratio) curbing measure implemented by the Singapore government at that time. 
time. Unfortunately, because of a difference in law between the two economies, ${ }^{8}$ the HKMA could not directly copy Singapore's eighth round of curbing measures. Neither were the monetary officials well-trained and capable enough to modify Singapore's curbing measures into one that would suit Hong Kong. As such, they did not implement any curbing measures while Singapore was able to further squeeze its (smaller) property bubble with its eighth round of curbing measures [27]. Coupled with further mistakes at that time, the property price index in Hong Kong made further rampant rises, which in turn increased the intensity of the changes in economic behaviors, the vicious cycles, the upward spirals, the financial leveraging and the herding behavior at that time. As a result, the rise in Hong Kong property index between March 2009 and end 2017 was $227 \%$ (i.e., 3.27 times), while the rise in Singapore during the same period was only $38.6 \%$.

\subsubsection{Further Lessons from the Above Experience}

While Singapore managed to squeeze part of its property bubble during the development stage with severe enough curbing measures, the author was puzzled why the Singapore government missed the best chance to pre-empt the bubble at the seeding stage despite the fact that Singapore monetary and economic officials were impressed by the author's advance warning in August 2009. One possible reason could be the property market and the economy were at the early stage of the recovery so that these officials would rather err on the recovery side instead of taking the risk of a double dip. ${ }^{9}$ While this could be a rational choice for the case of economic recovery, the discussion in Section 3.1 suggests that it might not be a good choice for a healthy recovery of the property market. That is, if we leave the recovery or rise of property prices unattended for a few quarters, the upward inertia will create an expectation of further rise in property prices, which could push the property market onto an automatic path towards a bubble through substantial changes in economic behaviors, powerful vicious cycles, development of upward spirals, rise in financial leverages and emergence of herding behavior. Thus, to strike a balance between the risk of a property bubble and the risk of a double dip due to too early a curbing and an unexpected negative shock in the seeding stage, the author would like to draw the following lesson from the above discussion:

4) If an asset market exhibited an uninterrupted rebound from the trough for more than six months (or three quarters), it might be worthwhile for the government to curb the rise so that the cumulated rise in the first 6 - 9 months could be reduced by $30 \%-50 \%$.

That is, it is worthwhile to engineer a mild correction so that the perceived risk of correction will make it more difficult for the market to form an expectation of further rise in the asset price. On the other hand, despite of the mild correction, there will still be a net recovery of the asset price to contain the risk of a double dip.

\footnotetext{
${ }^{9}$ The author would like to thank Professor Y. K. Tse for the suggested explanation.
} 
On top of that, the author would like to add the following lesson drawn from the asset bubble before the 1997-98 Asian financial crisis, the Chinese stock market bubble in 2006-07 and the property bubble experience in Hong Kong and Singapore in 2009-18:

5) Expectation could be very stubborn during the asset boom, but very fragile during the plunge. For example, during the asset inflation period or the development stage of an asset bubble, even if the government introduces a lot of curbing measures, many people would still want to buy the asset. However, when the asset price starts to fall, even if the government introduces a lot of supporting measures, most market participants still want to sell the asset.

\section{Some Important Characteristics of Financial Crises}

To gain insight on the development of a financial crisis and to draw lessons on the related policy measures, the author will partition a full-blown financial crisis into the following three stages: the early stage, the full-blown stage, and the post-crisis recession. While there would be reversals of financial leverage, expectation, changes in economic behaviors, vicious cycles, spirals and herding behaviors in the downward direction, the orders and logics of these events may be different from those in an asset bubble. Thus, it is still necessary to go through the characteristics in each stage.

\subsection{The Early Stage of a Financial Crisis}

\subsubsection{The First Fall and Then the Beginning of a Downward Inertia}

As explained in Section 3.2, in the final stage of an asset bubble where close to $100 \%$ of the potential investors have already invested close to $100 \%$ of their available funds in the asset, the rise in the asset price has to slow down and then stop. Thus, once the asset bubble reached the final stage, there would be two possible cases. The first case is where there is no large enough negative shock to trigger the bursting at the early part of the final stage. In such a case, the bubble would have the chance to grow to a gigantic one so that even a very mild negative shock is enough to trigger a bursting of the bubble. The second case is where there is a large enough negative shock that trigger a bursting of bubble at the early part of the final stage. Whatever the case, once the bubble reaches the final stage, there will sooner or later be a fall in the asset price.

As the assert price is substantially overvalued at this stage, once there is a meaningful first fall, some asset holders will be induced to sell the asset before it is too late and many highly leveraged investors will be forced to sell the asset. This will cause further fall in the asset price which will in turn trigger more and more asset holders selling the asset, thus resulting in a downward inertia in the asset price. Nevertheless, the pattern of this process in the property market could be very different from that of other financial markets such as the stock market, the commodity market and the foreign exchange market. Thus, it is necessary to discuss the two cases separately. 
1) The initial financial deleveraging and the beginning of a downward inertia in the financial asset market

Let us first consider the case of financial asset markets in which there is an organized exchange or over-the-counter trading platform so that the homogeneous assets could be traded in just a few seconds with very low transaction costs. Once there is the first fall, many of these asset holders will try to rush in front to each other to sell the asset, which will cause further fall in the asset price, and induce (or force) more asset holders to sell the asset. When more and more investors do so, the selling will cause a quick and sharp plunge in the financial asset price. Such a pattern is further aggravated by the investors' knowledge or previous experiences that falls in financial asset prices from the overvalued levels are usually quick and sharp. That is, many experienced investors will try to sell a significant amount of the financial assets at the initial stage of the correction.

Worse still, once the asset price started the plunge, the built-in leverage in the financial asset market will force or induce a change in the financial leverage and hence further plunges in the asset price. For example, some asset investors using shares financing will be forced to sell the shares if they do not have enough cash or asset to top up the margin ratio. Some investors in the stock futures market, commodity futures market and currency futures market will be forced to unwind their long positions if they do not have enough cash to top up the deposit. Meanwhile, more funds and individual investors will find it necessary to hedge their risk, and more institutional and individual participants will find it profitable to take huge short positions through the related derivatives markets. For examples, some institutional and individual participants in the mother asset (e.g., shares, commodities and foreign exchanges) will hedge their risk by selling the related futures (e.g., stock futures, commodity futures and currency futures), while some institutional and individual speculators will find it potentially profitable to sell the related futures. Through arbitrages, the above leveraged selling pressure in the futures market will be transmitted into enormous selling pressure in the mother asset. For the case of shares, some hedgers or speculators will also buy put options or callable bear contracts. As the issuers of these derivatives will need to hedge at least part of the risk, the leveraged activities in the stock derivatives market will be transmitted into substantial selling pressure in the mother shares. As a result, the initial plunge in the financial asset price will trigger further fall in the asset price.

\section{2) The downward inertia in the property market}

For the case of property market, the pattern of the fall might be different because of the higher transaction costs and longer time involved in doing the one-to-one bilateral trading of the heterogeneous asset (i.e., properties could be very different from each other in terms of location, quality, window view and direction, floor level and so on). In addition, unlike the financial assets, properties also play the important role of meeting the housing needs of most property owners. Thus, most property owners will try to hold their properties and honor 
the mortgage installment at the early stage. In addition, in the case that a mortgagee cannot pay the installment on time, the banks will at least need to wait for six months before they can start to take the property back. Thereafter, it will take another few months before the banks can successfully sell the property in the market. Thus, only a relatively small portion of property owners will sell their properties voluntarily at the very early stage. As a result, the selling pressure at the very early stage will not be that big so that the property market will usually be able to struggle in the first one or two years of the crisis. Nevertheless, when the market and economic condition continues to deteriorate or when banks start to sell their properties, the selling pressure will increase and property prices will start to make more meaningful fall. This will in turn induce or force more and more property owners to sell, thus resulting in a downward inertia in the property prices.

While the initial fall in property prices may not be as sharp and abrupt as the initial fall in the financial asset prices, it should be noted that a bursting of property bubble is usually more damaging than a bursting of most financial asset bubble of the same size. Take the difference between the stock market and property market as an example. While there are many shares investors, it is also true that there is a large number of households never invest in shares. Furthermore, the average dollar amount of shares investment is usually much smaller than that of property investments. Among the shares investors, there is also a significant portion of participants who choose not to use any financial leveraging facilities. On the other hand, the widespread existence of mortgage loans implies that there is usually a high leverage in property ownership (e.g., a 20\% down-payment would imply a gearing of 5 times, which is much greater than that of standard margin trading of shares).

On top of that, there are also a lot of property related assets such as property shares, real estate investment trusts (REITs) and banks shares. All these assets (including the banks shares) will plunge with the collapse of property prices. Thus, the spillover effect of a plunge in property price will be substantial. In addition, there could be huge amount of property derivatives such as the collateral debt obligations (CDOs) and mortgage backed securities (MBS). The low liquidity of the CDOs during the crisis period will also cause substantial plunges in the asset price. Furthermore, insurance companies (such as the AIG) and mortgage institutions (such as the Fannie Mae and the Freddie Mac) providing the legally required insurance on mortgage backed securities will also suffer disastrous losses, which will in turn raise serious doubt on the stability of the financial system.

It should also be noted that, if the property price index or a financial asset price is not substantially overvalued, a sharp plunge in the asset price will attract some bargain hunters so that there will be a low enough but not too far away price that the asset market can stabilize after the initial plunge. In such case, there will not be a financial crisis. However, if the asset price is substantially overvalued, such as the case with a medium or large bubble, the initial selling 
pressure will be much greater than the initial bargain hunting. This is particularly the case if there is a decent percentage of rational bargain hunters who will only bargain hunt after the asset price fall to a "fair" or substantially low level. That is, while the initial selling during the first fall from the bubble will be large, the initial bargain hunting will be small. In such case, there will be further fall in the asset price. The downward inertia will in turn trigger an expectation of further fall in the asset price and hence a large number of negative changes in economic behaviors, vicious cycles and downward spirals, which will bring the economy into a full-blown crisis such as that discussed in Section 4.2.

\subsubsection{Expectation of Further Fall in Asset Price and Changes in Economic Behaviors}

Thus, in the case of an asset bubble, the initial fall will trigger a downward inertia and hence an expectation of further fall the in asset price. The latter will in turn cause a large number of negative changes in economic behaviors, which will fuel further plunges in the asset price. For example, many shares investors experiencing heavy losses during the plunge may refrain from making more shares investment. Those who cannot stand the psychological pressure will even sell all their shares and exit from the stock market for many years. Mutual funds and other large investment funds will experience heavy redeeming pressure from both institutions and individuals, which will force them to sell the shares. There will also be sharp reduction and abrupt disappearance in the inflows of new shares investors. In addition, there will be more and more institutional and individual speculators taking heavy short positions because of the expectation of further fall in the asset price. There will also be a further surge in hedging and speculating activities such as those discussed in Part A of Section 4.1.1. As explained in the subsection, all these highly leveraged speculating and hedging activities in the stock futures, stock options and callable bear contracts will result in enormous selling pressures in the mother shares.

In the case of an exchange rate crisis, the downward inertia of exchange rate and expectation of further fall in the exchange value of the currency will induce exporters and those domestic residents with foreign currency to delay or stop remitting the foreign currency back home. The downward inertia and expectation will also induce importers and other domestic residents to speed up outward remittance and start making capital flight out of the economy. In addition, more participants will hedge their exchange rate risk through substantial leveraged selling in the currency futures. Worse still, more and more domestic residents, hedge funds and international speculators will take huge leveraged short positions in the currency futures market. Through covered interest arbitrage, all these hedging and speculative activities will be transmitted into enormous selling pressure in the spot exchange rate market, and a liquidity crunch in the domestic money market [9].

In the property market, there will also be an increase in the supply of properties when more property owners are induced or forced to sell their properties. 
With the expectation of further fall in property prices, there will also be a substantial reduction or abrupt disappearance of speculative demand, investment demand and panic demand for properties. Thus, there will be a substantial increase in the supply of properties and an abrupt reduction in the demand for properties. These will cause a further fall in the prices of properties, other property-related assets and property derivatives, thus providing the necessary fuel to push the whole financial system towards a full-blown crisis such as that described in Section 4.2.

\subsubsection{Changes in Economic Behaviors on the Monetary Side}

Along with the above changes in economic behaviors in the direct demand for and the supply of the asset, there will also be changes in economic behaviors on the monetary side. For example, with the expectation of further fall in the asset price, the general public will substantially increase their desired cash-to-deposit ratio $(k)$, partly because of the desire to reduce asset investment and partly because of a much greater failure risk of financial institutions. Banks will also substantially increase their desired excess-reserve-to-deposit ratio (e), partly because of a sharp surge in the adverse selection problem and the moral hazard problem in their loan business and partly because of the need to keep more excess reserves to meet the subsequent adversity. That is, with the start of the financial crisis, the used-to-be safe borrowers might no longer be a safe borrowers (i.e., the adverse selection problem), as the related borrowing firms might start to make loss in their business and the related individual borrowers might lose their job during the crisis. There is also a surge in the risk of borrowers using the bank loans to cover their other losses instead of using it for the purpose stated in the loan application form (i.e., the moral hazard problem). Meanwhile, to reduce the risk of a bank run which might result in forced takeover of the bank by the government or by another bank selected by the government, banks will try to keep more excess reserves to minimize the risk of a bank run. According to equations (4) and (4'), the substantial increase in $k$ and $e$ will cause a substantial reduction in the money multiplier $(m)$. To illustrate the potential impacts of the change, the author has plotted in Figure 3 his computed M2 money multiplier in the US before and after the financial tsunami in 2008-09. As we can see, there was a $40 \%$ - $60 \%$ reduction in money multiplier from 8 - 9 times to $4-5$ times. According to Equation (3), i.e., $M=m \times M B$, such a large reduction in the $m$ will ceteris paribus cause a $40 \%-60 \%$ reduction in the money supply (i.e., even if there was no reduction in the monetary base $M B$ due to capital outflows). Without any offsetting policy measures, such a $40 \%-60 \%$ reduction in money supply will by itself be enough to pull the US economy and then the global economy into a great depression. In Section 4.4, the author will highlight the policy implications of such a discussion on the changes in economic behaviors on the monetary side.

On top of the substantial reduction in the money multiplier $(m)$, there could also be substantial and ongoing reduction in the monetary base $(M B)$ for the case of an exchange rate crisis. For example, during the Asian financial crisis in 


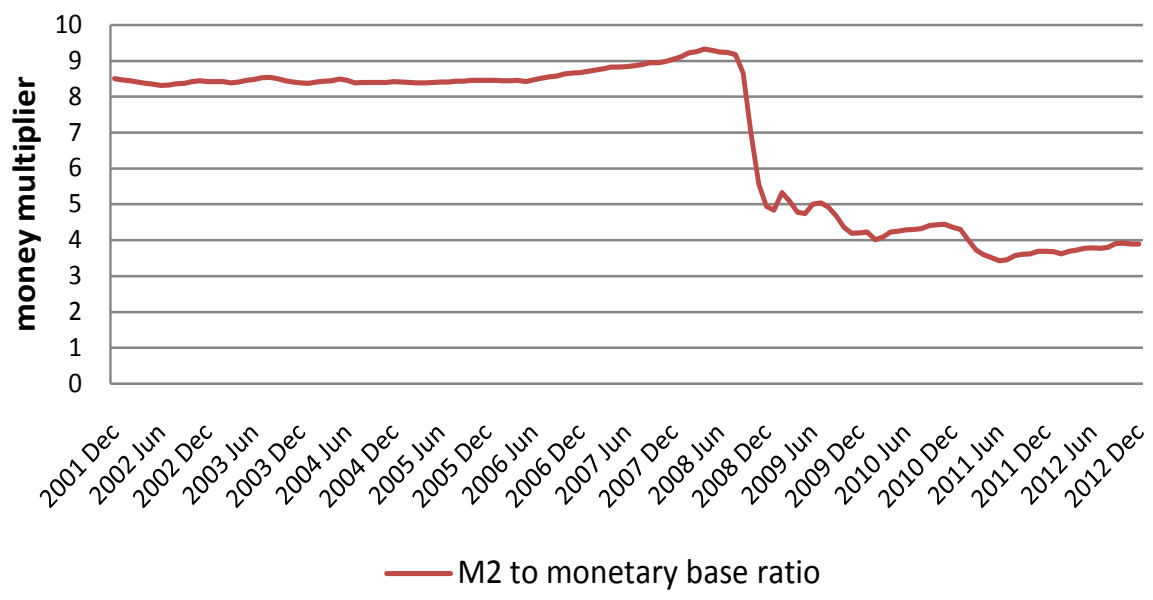

Figure 3. US money multiplier (M2/MB).

1997-98, plunge in the exchange value of domestic currency had triggered enormous short-term capital outflows from Thailand (and some other crisis-affected Asian economies) in both the early stage and the full-blown stage of the crisis. The outflows had in turn resulted in a substantial reduction in the monetary base and hence a liquidity crunch in each of the affected economy. Furthermore, as pointed out in Part B of Section 3.1.1, banks and non-bank financial institutions in these economies were using short-term foreign currency loans to finance their domestic loans and investment during the bubble period. With the start of the plunge in the exchange value of the domestic currency, these financial institutions were no longer able to roll over the short-term foreign currency loans, which would mean that they had to pay back the foreign currency when the short-term loans reached the due time. Thus, there was not only an abrupt disappearance of short-term capital inflows but also a sharp surge in capital outflows when these domestic financial institutions sold the domestic currency so as to get the foreign currency for the loan repayment. This would also imply a substantial reduction in the monetary base and a liquidity crunch at the early stage and the full-blown stage of the crisis.

In addition, during the early stage and the full-blown stage of the financial crisis, there would be a lot of foreign hedge funds as well as domestic speculators and hedgers doing substantial selling in the domestic currency futures market. Through the covered interest arbitrage, the selling pressure in the currency futures market will be transmitted into enormous selling pressure in the spot exchange rate market and a squeeze of monetary base and hence multiple contraction of money supply in the domestic money market.

In short, throughout the early stage and the full-blown stage of the crisis, there will be ongoing changes in economic behaviors on the monetary side, and these changes will cause a substantial reduction in the money multiplier $(m)$ and monetary base $(M B)$. Without strong enough offsetting measures, these changes would by itself be enough to pull the economy into a depression. 


\subsection{From the Early Stage to a Full-Blown Crisis: Some Disastrous Vicious Cycles}

With the expectation of further fall in the asset price and the ongoing changes in economic behaviors outlined in Sections 4.1.2-4.1.3, there would be further fall in the asset price. This will in turn trigger a few disastrous vicious cycles, which could push the whole financial system into a full-blown crisis. ${ }^{10}$ For example, while the highly-leveraged or mis-managed financial institutions might manage to survive at the early stage of the crisis, ongoing fall in the asset price will mean ongoing increase in their financial losses and ongoing reduction in their available funds. Sooner or later, one of the most mismanaged financial institutions will run out of cash and need to declare default. By then, news of the default will raise concern on the survivability of the other mismanaged financial institutions, which will trigger more failures of financial institutions and non-financial firms, thus resulting in a vicious cycle between a higher perceived risk of a systemic failure in the financial system and more failures of financial institutions and non-financial firms.

In addition, there could be a vicious cycle between more bad news and further plunge in asset prices. That is, with news on the failure of some over-leveraged financial institutions, property prices, shares prices and other financial asset prices will plunge further. The latter will bring more financial institutions and non-financial firms into illiquidity or insolvency problems, and news about that will cause further plunges in the asset prices.

There will also be a vicious cycle between the fall in asset prices and loss provision. That is, according to the mark-to-market rule, banks, non-bank financial institutions and other listed firms have to value their assets according to the market price. With a fall in these asset prices, the listed companies have to make a loss provision even though it is just a paper loss (i.e., even if these companies never sell the asset with a realized loss throughout the whole crisis). Such a loss provision will in turn reduce the profits (or increase the losses) of the listed firms, which will in turn cause further plunges in the shares prices when these companies release their quarterly earnings results. Worse still, there will be a vicious cycle between the fall in asset prices and fire sales of assets. That is, the above loss provision by banks will have to be matched with a reduction in the banks' capital, thus resulting in a drop in their capital-asset ratio below the acceptable norm (i.e., 8\% for case before the 2008-09 Global Financial Tsunami). As it will be difficult for the banks to raise capital during the financial crisis, banks has to restore their capital-asset ratio by selling their assets. However, with a capital-asset ratio of $8 \%$, every one billion dollars of loss provision will mean that the bank has to sell 12.5 billion dollars of assets. Such a huge fire sales by the ${ }^{10}$ Note that not every bursting of asset bubble will end up as a full-blown systemic financial crisis. If the asset bubble is not that connected with the other parts of the economy or the size of the asset bubble is not that big, the bursting might just end up as a mini crisis in that particular asset market. For example, if it is just a bursting of a very specific commodity bubble (such as a collapse in the price of gold, silver, copper, soya bean or bitcoin), the damage of the bursting might be quite localized with only limited spillover effect to the other parts of the economy. 
banks will obviously cause a severe plunge in asset prices, which will in turn cause another round of loss provision and fire sales. Experience from the 2008-09 financial crisis in the US suggests that the vicious cycle could be explosive. That is, because of the existence of huge amount of toxic assets such as CDOs and MBS in banks' and non-bank financial institutions' portfolio, without the help of the US government, the vicious cycle would cause a deeper and deeper fall in asset prices as well as widespread failures of banks, non-bank financial institutions and non-financial firms. Similarly, experience from the European Debt Crisis in 2010-12 suggests that the vicious cycle between falling sovereign bond price and banks' fire sales of the sovereign bonds could be explosive. That is, without the rescue package by the European Central Bank at that time, there could be a large number of sovereign bond defaults and widespread collapse of banks and financial institutions in Europe until the European financial system failed to function properly.

For the case of an exchange rate crisis, with the ongoing capital outflows and speculative attacks in the currency futures market discussed in Section 4.1.3, governments attempting to defend the currency value will keep seeing their foreign reserves falling. Sooner or later, they will be forced to give up and accept a substantial plunge in the exchange rate, which will in turn trigger a series of disastrous vicious cycles. For example, there will be a vicious cycle between further plunge in the exchange rate and further capital flight, a vicious cycle between further capital flight and further liquidity crunch (and further surge in domestic interest rate), a vicious cycle between further liquidity crunch and further plunge in property prices and financial asset prices, and a vicious cycle between further plunge in domestic asset prices and further capital outflows (and hence further plunge in the exchange rate). That is, the plunge in the exchange rate will induce more capital flight and more capital outflows through more speculation and hedging activities in the currency futures market, which will in turn cause further plunge in the exchange rate. More capital outflows will also cause further squeeze in the monetary base and hence multiple contraction of money supply and a greater degree of liquidity crunch (and further rise in interest rate) in the domestic money market, which will in turn cause further plunge of property prices and shares prices. Risk of further fall in these asset prices will induce further capital outflows and hence further plunge in the exchange rate. Experience from the Asian financial crisis in 1997-98 suggests that the extent of capital outflows, liquidity crunch and surge in domestic interest rate as well as the cumulated fall in the exchange rate, property prices and shares prices were substantial.

\subsection{The Post-Crisis Recession}

When the economy and its financial system reach the above full-blown crisis stage, there will be emergence of more vicious cycles and downward spirals, which will push the economy into a prolonged post-crisis recession (i.e., many years of recession beyond the crisis period). For examples, in addition to the vi- 
cious cycle between further fall in property prices and further fall in financial asset prices, there will be a series of vicious cycles among further fall in asset prices, further fall in consumption, further fall in investment, and further fall in output. That is, further fall in asset prices will mean lower wealth for consumer and hence further fall in consumption through the wealth effect. The reduction in consumption will in turn trigger a multiple contraction of output through the standard multiplier effect. In addition, through the Tobin's q effect, further fall in property prices will cause further reduction in developers' investment in real estate development, and further fall in shares prices will cause further reduction in firms' investment. The fall in investment will again cause a multiple reduction in output through the standard multiplier effect, while the fall in output will cause another round of reduction in investment through the accelerator effect. Furthermore, the fall in consumption, investment and output will cause lower demand for asset, and hence more rounds of fall in asset prices and fall in aggregate demand.

There will also be a downward spiral when lower output and higher unemployment cause a lower wage, rental and general price, which will in turn mean weaker support for property prices and shares prices. By then, the economy will be trapped by a prolonged post-crisis recession with negative output growth, high unemployment as well as slowly falling wages and prices.

\subsection{Lessons from Policy Measures Adopted during the Financial Crises}

Unlike the case of the bursting of stock market bubble before the Great Depression in the 1930s, the Global Financial Tsunami in 2008-09 and the European Debt Crisis in 2010-12 were only followed by severe recessions instead of great depressions in the related countries. Thus, a careful review of the policy measures in these crises could provide us valuable insight on potential policy measures that could be used to mitigate the economic pains triggered by a financial crisis in the future.

\subsubsection{Lessons from the Global Financial Tsunami}

As pointed out in Section 4.1.3, changes in economic behaviors on the monetary side had caused a $40 \%-60 \%$ reduction in the money multiplier $(\mathrm{m})$ during the US financial tsunami in 2008-09. Without sufficient offsetting policy measures, the implied $40 \%-60 \%$ reduction in money supply would by itself be enough to pull the economy into a great depression similar to that in the 1930s. Our model in Part B of Section 3.1.1 also suggests that the money multiplier $(m)$ would depend on the behavioral parameters $k$ and $e$, and it would be difficult for the government to reverse the substantial changes in these behavioral parameters. However, Equation (3), i.e., $M=m \times M B$, also suggests that the government could offset the effect of the substantial decline in $m$ by a substantial increase in $M B$ through aggressive purchase of government bonds, which is later known as the Quantitative Easing. 
The equation also suggests that the government has no choice but to be brave enough to engineer a huge increase in the monetary base $(M B)$. That is, without the theoretical framework in Section 3.1.1, the related government is unlikely to know the disastrous consequence if it does not engineer the huge enough increase in monetary base. As such, it might just make no attempt to increase the monetary base (as was probably what the Federal Reserve in the 1930s did), or just make a far from sufficient increase in the monetary base (as was probably what the Japanese central bank did during the lost decades after the bursting of Japan's property bubble and stock market bubble in the late 1980s). Thus, to avoid the mistakes during the Great Depression and the lost decades in Japan, the US government had no choice but to be courageous enough to engineer a gigantic and huge enough injection of monetary base.

Fortunately, although Bernanke and his colleagues in the Federal Reserve were not equipped with the author's new theoretical framework outline in Section 3.1.1, they were aware of the importance of monitoring the money supply and avoiding it from substantial plunges. That is, even without the author's new theoretical framework on the drastic decline in the money multiplier due to substantial behavioral changes during the crisis period, they knew that they had to keep the money supply from falling by aggressive purchase of government bonds (i.e., the Quantitative Easing).

As shown in Figure 4, the Federal Reserve was knowledgeable and courageous enough to inject gigantic amount of high power money through the Quantitative Easing programs so that the money supply could exhibit a moderate increase without any fall during the whole crisis period. That is, the Quantitative Easing programs helped the US to avoid a great depression by offsetting the $40 \%-60 \%$ fall in money multiplier by the gigantic increase in its monetary base.

Along with the Quantitative Easing programs, there were also a few important policy measures that helped the US economy from dipping into a deeper crisis with more severe recession. Firstly, the US Treasury used the Trouble Asset Relief Program (TARP) to inject capital into financial institutions (such as the Citigroup and the AIG) as well as non-financial firms (such as the General Motor,

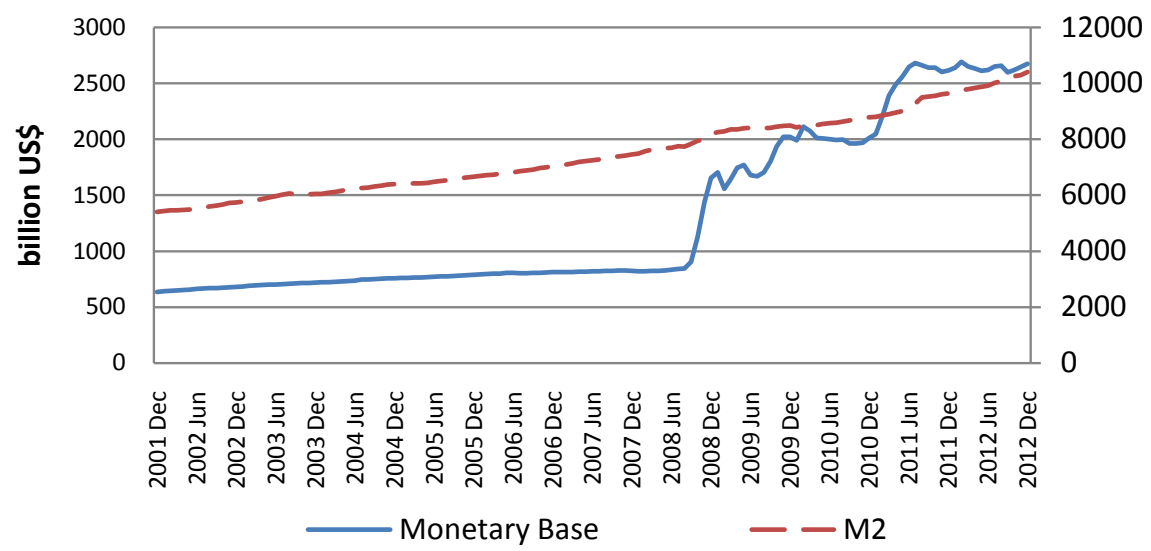

Figure 4. US monetary base and M2. 
Chrysler and Ford). Such an injection helped avoid the expected failures of these companies, thus avoiding the enormous spillover effects to many other companies. The injection of capital into the banks and non-financial institutions also helped them out of the vicious cycle between more asset fire sales and further fall in asset prices. In fact, as the TARP funds was targeting the capital of these financial institutions, the effectiveness of each dollar of TARP funds spent was much greater than that of the Quantitative Easing programs.

To further help the banks and non-bank financial institutions out from the vicious cycle between more asset fire sales and further fall in asset prices, the US government also temporarily allowed these financial institutions to replace the mark-to-market rule by a less demanding long-term valuation rule with effect from March 2009. As a result, the vicious cycle was broken as banks and non-bank financial institutions were no longer forced to do the loss provision and asset fire sales. In fact, together with the help of the other policy measures, the change in the accounting rule had contributed to the stabilization and then the strong rebound of the US stock market from late March 2009.

Finally, to restore market confidence on the US financial institutions, the US government also announced that it would conduct a stress test on these financial institutions. Perhaps most crucial and interesting is that these financial institutions were given a few months time to raise capital from the market before the stress test. That is, the aim of the arrangement is to force these financial institutions accepting the pain of issuing new shares at a low price amid the crisis so that the capital raised would bring these financial institutions back to healthy enough positions to pass the stress test. In other words, the aim of the arrangement was twofold: force the financial institutions to raise capital to healthy levels, and then let them pass the stress test which would restore market confidence on them over time.

Because of these measures, the US financial system was able to stabilize, which cause a strong rebound of the US and global stock markets by removing the "fear discount" of a potential failure of the US financial system.

Thus, the above discussion suggests that measures like the Quantitative Easing, the TARP, the temporary change of the mark-to-market rule and forcing the financial institutions to raise capital to pass the stress test could be very useful tools to fight against a future financial crises by stopping further deterioration in the financial system, removing the fear discount of a failure of the financial system, and hence triggering a rebound of the financial asset prices from the over-corrected level.

\subsubsection{Lessons from the European Debt Crisis}

During the European Debt Crisis, political problems among the European Union (EU) members had however resulted in a delay in the use of the European version of Quantitative Easing $(\mathrm{QE})$. As a result, the sovereign debt crisis had caused a rapid deterioration of the European economy. Fortunately, the European Central Bank (ECB) was eventually allowed to announce its own version of 
QE (i.e., the Long Term Refinancing Operations, LTROs and the Outright Monetary Transactions, OMTs), which had helped the stabilization and then the strong rebound of the sovereign debt markets of the crisis-hit economies. Meanwhile, the disappearance of the fear discount of a potential collapse of the whole European financial system had also triggered a strong rebound of the European and the global stock markets. Nevertheless, while the EU had also implemented the stress tests on its financial institutions, it did not force the financial institutions to take the pain to raise capital by issuing new shares at the low "crisis prices". As such, European banks and non-bank financial institutions were in fact far from healthy positions. Together with the damages due to the delay in the use of QE, this had contributed to a much weaker European economy during the post-crisis period when compared with that of the US. Thus, the above comparison between the EU and the US suggests that unnecessary delay in the use of QE would give the crisis more time to cause damages on the economy, which would in turn imply weaker recovery of the economy. In addition, the arrangement of forcing the financial institutions to take the pain to raise capital before the stress test is important. Without this, the financial institutions will remain weak and unhealthy, thus making them less able to provide the necessary funds and services to support the economic recovery.

\subsubsection{Lessons from China's Ultra Fiscal Expansion}

Before the implementation of the QE, the US government had once attempted to use fiscal stimulation to offset the negative impact of the financial crisis. Nevertheless, as the deepening of the financial crisis at that time had already caused substantial deterioration of the economy, the fiscal stimulation was too late and too small to stop or slow down the deterioration. However, recognizing that it would take time for the financial crisis in the US at that time to create a downturn in the Chinese economy, the author proposed to use ultra fiscal expansion to avoid the Chinese economy from being pulled into a recession. ${ }^{11}$ This will in turn help China's financial system from going into a financial crisis with a series of powerful adverse changes in economic behaviors, financial deleveraging, vicious cycles and downward spirals such as those discussed in Section 4.2. That is, while the US was already in a financial crisis so that it was too late to use fiscal policy to achieve an effective stimulation, China was still not yet in a financial crisis or recession. Thus, it would be effective for China to use ultra fiscal expansion to stop the Chinese economy from being pulled into a severe recession, which could trigger a financial crisis in China amid the global crisis at that time. On the other hand, if China let these forces to kick in, the same size of fiscal expansion will be far less effective, as most of the stimulation had to be used to offset the negative impacts. In other words, if China took the advantage of the difference between its position in the economic cycle and the US position at that time by starting the fiscal expansion early, the required amount of fiscal expan-

${ }^{11}$ The proposal was submitted to the Chinese leaders as an internal report through the Xinhua News Agency. It was also published in the Hong Kong Economic Journal, a major financial newspaper in Hong Kong. 
sion would be much smaller. Fortunately, after a debate with the then Governor of the Chinese central bank, the Chinese leaders had finally taken the view that an ultra fiscal expansion was necessary at that time. Because of the ultra fiscal expansion (later known as the four trillion fiscal expansion), China managed to avoid being pulled into a financial crisis with a severe recession. That is, it only experienced a moderate reduction in real GDP growth without a financial crisis during the global financial tsunami. ${ }^{12}$

\section{Conclusions}

In this paper, the author has gone through the major characteristics of asset bubbles and financial crises. Understanding these characteristics is a pre-requisite for having the right policy option and timing during the various stages of an asset inflation period or a financial crisis. For example, during the asset bubble period in many Asian economies in 1990-97, because of the absence of appropriate theories on the characteristics of the three stages of an asset bubble, the central bankers in these Asian economies failed to recognize the need to pre-empt the formation of an asset bubble at the seeding stage. As a result, the sustained rise in the asset prices and expectation of further rise in asset prices at that time had the chance to push these economies onto automatic paths towards gigantic asset bubbles. Worse still, without the right theoretical tool on the development stage of an asset bubble, they also failed to understand that they had to use very severe curbing measures to stop the bubble from growing. Instead, they just gave up so that the bubbles at that time had the chance to grow further until the extremely damaging bursting in 1997-98.

With the theoretical framework in Section 3, the author was able to identify the risk of a stock market bubble in China in mid-2006 (i.e., the seeding stage of the 2006-07 bubble), and the risk of property bubbles in Singapore and Hong Kong in August 2009 (i.e., the early stage of the sustained rebound from the global financial tsunami). The theoretical framework in Section 3.1.2 also helped him to urge the related governments to implement severe curbing measures during the development stage of the asset bubbles. While China and Singapore had for some reasons failed to pre-empt the formation of the asset bubbles at the seeding stage, they did implement severe enough curbing measures in the development stage. As a result, the not-too-late curbing in China had helped it avoid a more disastrous bursting of its stock market bubble, while the severe curbing in Singapore had gradually squeezed its moderate property bubble into a much smaller and safer bubble. ${ }^{13}$

\footnotetext{
${ }^{12}$ Having said that, there were some costly abuses at that time. For example, because of some local governments' abuses of the four trillion fiscal expansion, there were some infrastructure projects eventually ending up as white elephant projects.

${ }^{13}$ That is, the small bubble would not be able to burst by itself. Nevertheless, if there is a bursting of property bubble in another economy (e.g., Hong Kong or India), the contagion effect would still be able to pull Singapore's property prices from a slightly overvalued level to a moderately undervalued level. That is, Singapore would still suffer a mini crisis, should a bursting elsewhere trigger another Asian financial crisis.
} 
Unfortunately, despite the author's two visits to the HKMA and repeated warnings in the press, economic and financial officials in Hong Kong were not well-trained or responsible enough to pre-empt the bubble formation at the seeding stage or designed severe enough curbing measures to stop its property from growing in the development stage and the final stage. According to the characteristics outlined in Section 3, the property bubble in Hong Kong should by now (i.e., March 2018) be at the middle part of the final stage. In fact, the related economic and financial officials have already given up any attempt to curb the property bubble, as any meaningful curbing could trigger a bursting so that they would be blamed for such an action. As a result, as predicted by the theoretical framework in Section 3, Hong Kong's property bubble continued to grow rapidly to a more dangerous one. According to the same theoretical framework, a bursting of the property bubble would be just a matter of time, and such a bursting will trigger a full-blown financial crisis in Hong Kong. To the extent that some other Asian economies (such as India, Taiwan and Malaysia) had also a large or moderate property bubble, the bursting in Hong Kong could trigger another Asian financial crisis in the foreseeable future.

Understanding the characteristics of the various stages of a financial crisis is also important. For example, with the help of the theoretical framework outlined in Section 4, the author was able to convince the Chinese government to implement its four trillion yuan fiscal expansion before China was pulled into a recession during the early stage of the financial crisis in the US in 2008. Because of the early stimulation, China was able to avoid a financial crisis and only experience a moderate reduction in real GDP growth during the global financial tsunami.

At the early part of the full-blown stage of the global financial tsunami, the Federal Reserve and the US government was quick to identify some of the disastrous vicious cycles outlined in Section 4 , and was able to reduce the impacts of these vicious cycle by the Quantitative Easing, the TARP, the temporary replacement of the mark-to-market rule by a long-term valuation rule, and requesting the financial institutions to raise capital before the stress test. From the experience during the global financial tsunami, these measures could also be used to fight against financial crises in the future. Experience during the European Debt Crisis also suggests that unnecessary delay in the use of the Quantitative Easing and failure to force the financial institutions to raise capital back to a healthy level would imply a longer recession, weaker recovery and a less healthy financial system.

\section{References}

[1] Frankel, J.A. and Froot, K.A. (1986) The Dollar as a Speculative Bubble: A Tale of Chartist and Fundamentalist. NBER Working Paper, No. 1534. https://doi.org/10.3386/w1854

[2] Frankel, J.A. and Froot, K.A. (1987) Using Survey Data to Test Standard Propositions Regarding Exchange Rate Expectations. American Economics Review, 77, 133-153. 
[3] Radelet, S. and Sachs, J.D. (1998) The East Asian Financial Crisis. Brooking Papers on Economic Activity, 1998, 1-74. https://doi.org/10.2307/2534670

[4] Furman, J. and Stiglitz, J.E. (1998) Economic Crises: Evidence and Insights from East Asia. Brookings Papers on Economic Activity, 1998, 1-114. https://doi.org/10.2307/2534693

[5] Hutson, E. and Kearney, C. (1999) The Asian Financial Crisis and the Role of the IMF: A Survey. Journal of Asia Pacific Economy, 4, 393-412. https://doi.org/10.1080/13547869908724690

[6] Goldstein, M. (2001) The Asian Financial Crisis: Origins, Policy Descriptions and Lessons. Journal of African Economies, 10, 72-103. https://doi.org/10.1093/jae/10.Suppl1.72

[7] Yip, P.S.L. (2005) The Exchange Rate Systems in Hong Kong and Singapore: Currency Board vs Monitoring Band. Prentice Hall, Singapore.

[8] Yao, W. and Luo, D. (2009) The Economic Psychology of Stock Market Bubbles in China. The World Economy, 32, 667-691. https://doi.org/10.1111/j.1467-9701.2009.01176.x

[9] Yip, P.S.L. (2011) China’s Exchange Rate System Reform: Lessons for Macroeconomic Policy Management. World Scientific, Singapore. https://doi.org/10.1142/7491

[10] Xiong, W. and Yu, J. (2009) The Chinese Warrants Bubble. NBER Working Paper, No. 15481. https://doi.org/10.3386/w15481

[11] Powers, E. and Xiao, G. (2014) Mispricing of Chinese Warrants. Pacific-Basin Finance Journal, 30, 62-86. https://doi.org/10.1016/j.pacfin.2014.07.002

[12] Liu, D., Gu, H. and Lung, P. (2016). The Equity Mispricing: Evidence from China's Stock Market. Pacific-Basin Finance Journal, 39, 211-223. https://doi.org/10.1016/j.pacfin.2016.06.007

[13] Yip, P.S.L. (2016) China's Exchange Rate System Reform: Two Potential Mistakes and the Recommended Long-Term System. Singapore Economic Review, 61, Article ID: 1640025, 1-40. https://doi.org/10.1142/S0217590816400257

[14] Yip, P.S.L. (2018a) The Exchange Rate System Reform in China: US Pressure, Implicit Gradual Appreciation and Explicit Exchange Rate Bands. Working Paper, Economic Growth Centre, Nanyang Technological University.

[15] Cecchetti, S.G. (2009) Crisis and Responses: The Federal Reserve in the Early Stages of the Financial Crisis. Journal of Economic Perspectives, 23, 51-75. https://doi.org/10.1257/jep.23.1.51

[16] Mayer, C., Pence, K. and Sherlund, S.M. (2009) The Rise in Mortgage Defaults. Journal of Economic Perspectives, 23, 27-50. https://doi.org/10.1257/jep.23.1.27

[17] Coval, J., Jurek, J. and Stafford, E. (2009) The Economics of Structured Finance. Journal of Economic Perspectives, 23, 3-25. https://doi.org/10.1257/jep.23.1.3

[18] Shleifer, A. and Vishny, R. (2011) Fire Sales in Finance and Macroeconomics. Journal of Political Economy, 25, 29-48. https://doi.org/10.1257/jep.25.1.29

[19] Mishkin, F.S. (2011) Over the Cliff: From the Subprime to the Global Financial Tsunami. Journal of Economic Perspectives, 25, 49-70. https://doi.org/10.1257/jep.25.1.49

[20] Shambaugh, J.C. (2012) The Euro's Three Crises. Brookings Papers on Economic Activity, 2012, 157-231. https://doi.org/10.1353/eca.2012.0006

[21] Lane, P.R. (2012) The European Sovereign Debt Crisis. Journal of Economic Pers- 
pectives, 26, 49-68. https://doi.org/10.1257/jep.26.3.49

[22] Lothian, J.R. (2014). Monetary Policy and the Twin Crises. Journal of International Money and Finance, 49, 197-210. https://doi.org/10.1016/j.jimonfin.2014.04.004

[23] Panico, C. and Purificato, F. (2013) Policy Coordination, Conflicting National Interests and the European Debt Crisis. Cambridge Journal of Economics, 37, 585-608. https://doi.org/10.1093/cje/bet009

[24] Peersman, G. (2011) Macroeconomic Effects of Unconventional Monetary Policy in the Euro Area. CEPR Discussion Paper, No. 8348.

[25] Gambacorta, L., Hofmann, B. and Peeersman, G. (2012) The Effectiveness of Unconventional Monetary Policy at the Zero Lower Bound: A Cross Country Analysis. BIS Working Papers, No.384, Bank of International Settlement.

[26] Szczerbwicz, U. (2012) The ECB Unconventional Monetary Policies: Have They Lowered Market Borrowing Costs for Banks and Governments? CEPII Discussion Papers, No. 2012-36.

[27] Yip, P.S.L. (2014) The Risk of Property Bubbles in Hong Kong and Singapore: Another Aftershock Crisis of the Global Financial Tsunami. Singapore Economic Review, 59, Article ID: 1450026, 1-53. https://doi.org/10.1142/S021759081450026X

[28] Yip, P.S.L. (2018b) From the Global Financial Tsunami to the Property Bubbles in Asia. World Scientific, Singapore. 